\title{
AGRICULTURAL ENTREPRENEURSHIP, ENVIRONMENTAL PROTECTION AND INSURANCE
}

\author{
Vladimir Njegomir' ${ }^{1}$ Ljubo Pejanović2 ${ }^{2}$ Zoran Kekovic ${ }^{3}$
}

\begin{abstract}
Summary
Agricultural entrepreneurship is the basis of creativity, innovation, profitability and risk management of agricultural producers. Although the agricultural entrepreneurship is often ignored in Serbia, in the paper we emphasize its importance due to the fact that the contribution of agriculture still has the largest share in gross domestic product. Current 2016 was declared as the year of entrepreneurship in Serbia, which further stressed the importance of studying this problem. As the aim of the research we have determined the need for the study of agricultural entrepreneurship in the context of vulnerability to risks from the environment. In this regard, in the paper we first point to agricultural entrepreneurship and the importance of agriculture production in Serbia and then we point out to the environmental protection, as a form of preventive action for risk reduction, insurance, as a form of financing of insurance claims, and the characteristics of agriculture insurance in Serbia. The main conclusion is that environmental protection and agricultural insurance are complementary mechanisms of risk protection that provide significant support to agricultural entrepreneurship and the development of agricultural production.
\end{abstract}

Keywords: agriculture, entrepreneurship, climate changes, insurance, Serbia.

JEL: Q01, Q54, G22.

\section{Introduction}

Agriculture is economic activity old as human society. Agriculture is an economic activity in which primary product of plant and animal origin is received from exploitation of agricultural land and the cultivation of plants and animals. Those are processed on farms in order to meet

1 Vladimir Njegomir Ph.D., Associate Professor, Faculty of Law and Business Studies dr Lazar Vrkatić, Bulevar oslobođenja br. 76, 21000 Novi Sad, Serbia, Phone: +381 64139 30 05, E-mail: vnjegomir@eunet.rs

2 Ljubo Pejanović Ph.D., Associate Professor, Faculty of Law and Business Studies dr Lazar Vrkatić, Bulevar oslobođenja br. 76, 21000 Novi Sad, Serbia, E-mail: pejanovicljubo@gmail.com

3 Zoran Keković Ph.D., Full Professor, University of Belgrade, Faculty of Security Studies, Gospodara Vučića street no. 50, 11040 Belgrade, Serbia, Phone: +381 69123 02 65, E-mail: zorankekovic@yahoo.com

EP 2017 (64) 3 (1035-1047) 
personal and social needs. The development of human society led to the development of trade and transport so agriculture developed from production for own needs to commodity production. Farms were given the opportunity to supply market with their surplus agricultural products and to trade them for product and services from other economic activities.

Agricultural production is realized in business entities called farms. In Serbia, agricultural producers do not belong to entrepreneurs legally, but essentially they do, because they undertake business activities of agricultural production in order to generate profits.

One of the most significant factors of agricultural specificity is climate. Climatic elements significant for crop production are: air and soil temperature, humidity, cloudly and sunny weather, day length, quantity and distribution of rainfall, number off rainy days, the strength and direction of wind, the length of the winter, vegetation and frost-free period, etc. Periodic weather changes important to plant growth and development are: sudden changes, so-called excesses of the weather, such as frosts during the growing season, high temperatures, strong winds, droughts, floods, hail and similar.

Agricultural production is performed in the open and involves managing of living organisms, plants and animals what makes this production more complex and dependent on weather conditions, pests and diseases. Climatic factors often cause significant damage to agricultural production destroying all the efforts of entrepreneurship in agriculture. The negative impact of the climate is particularly evident in terms of climate change (Njegomir, Pejanovic, 2016).

The purpose of this paper is to determinate the need for the study of agricultural entrepreneurship and its vulnerability to the risks from environment. In this paper we first point on agricultural entrepreneurship and the importance of agriculture in Serbia and then on environmental protection as a form of preventive action to reduce the risk insurance, as a form of financing the result of damage realization and characteristics of agricultural insurance in Serbia.

\section{Methodology and data sources}

Our focus in this paper is entrepreneurship in agriculture in the context of environmental changes and posibilities for entrepreneurhip protection.

On the basis of foreign theorethical knowledge and empirical evidence we analyse agricultural entrepreneurship in general and in particular in Serbia. We use statistical analysis for data processing, analysing and presenting.

By using different legal sources we explain why farmers are acually entrepreneurs. We use data from CEFTA and World Bank to emphasise the role of the agriculture and entrepreneurship in agriculture in Serbia by using comparative data for regional countries and countries of the EU and the world.

We explore ecological crisis and environmental protection measures for protectiong 
agricultural entrepreneurship results. Also, we analyse the role of insurance as a protector of entrepreneurship activities in agricultural production in general and particularly in Serbia. We use data from National bank of Serbia to analyse in detail premium and loosses of crop and livestock insurance in Serbia.

\section{Agricultural entrepreneurship}

The first theoretical reference of entrepreneurship is associated to Cantillon who realized that entrepreneurs are individuals who accept risks and allocate resources to make use of available opportunities in order to maximize financial result (Cantillon, 1931). Schumpeter defined entrepreneurship in the context of new product and service development, the development of new production methods, identification of new segments and markets, iindetification of different sources of supply and the development different forms of organization (Schumpeter, 1934). Green Paper of the European Commission defines entrepreneurship as an individual capacity for identification and realization of opportunities in order to produce new value or economic success and it is independent or within the organization (Green Paper (2003).

Entrepreneurship essentially represents the identification of opportunities and the implementation of useful ideas into practice(ACS, 2008; Ireland, Webb, 2007). Etymologically the word "entrepreneur" comes from French word entre, that means "between" and prendre, that means "undertake". The word was originally used to describe people who "take the risk" between buyers and sellers or who undertake a task such as starting a new venture (Tyszka, et al., 2011). Entrepreneurship requires tasks that can be completed individually or in groups and these tasks usually require creativity, initiative and willingness to take risks.

This confirms that agricultural producers are basically entrepreneurs because they take risks in order to achieve positive business results. Also, agricultural producers individually or as a group with creative thinking and innovations increase their results both in primary agricultural production and expansion of entrepreneurship in multifunctional context (Stefanović, Obradović, Broćić, 2012) or in the context of the further processing of primary agricultural products.

There are other possibilities for entrepreneurial engagement of farmers. According to Lehmann, which is cited in McElwee (2005), the development strategies that actually represent entrepreneurial activities include the following: enlargement of capacity by expansion of land use, enlargement of capacity by expansion of animal production, different use of capacity by change of degree of specialization, enlargement of capacity by services and vertical integration, expansion of the non-agricultural employment, external business and co-operation with other farmers.

\section{Entrepreneurship in agriculture production in Serbia}

The average entrepreneur in Serbia is married, the father of one child, and before opening his own company he worked for other at least six years. Mostly he performed a service or some sort of craft activities for the previous employer or in the gray zone, and the third is an experience in agricultural production. In Serbia, agricultural production in post-war period 
had a dominate share in terms of the population (Birovljev, Tomić, 2009) and there was the greatest number of entrepreneurships in the period of socialism. Agriculture, as the most developed industry in Serbia, was the basic of entrepreneurship we have today.

Entrepreneurship is inseparably connected to agricultural production in Serbia. However, this connection stems from the interpretation of entrepreneurship as a "undertake" of business activities. Unfortunately, in Serbia entrepreneurship in agriculture in terms of combining primary agricultural production and the next phases of processing of primary agricultural products does not exist. Also, often agricultural production is realized only in the form of growing certain crops types that barely allows the return in investments. Entrepreneurship partially occurs in fruit growing, for example in growing hazelnut and raspberry, and also occurs in farming and animal husbandry at the same time.

A partial problem occurred in inadequate treatment of individual agricultural producers in legal meaning. The individual farmer is not an entrepreneur in term of Article 83 of the Company Law (2015) unless otherwise is regulated by a special law. On the other hand, in accordance with Article 31 and Article 32 of the Law on Personal Income Tax (2015) agricultural producer is exempt. According to the interpretation of the Ministry of Finance of the Republic of Serbia (MFRC, 2016), an individual that earns income by performing activities of agriculture and forestry, and income from the sale of agricultural and forest products acquire the status of entrepreneur: 1) by the force of the law - if the payer of value added tax is in accordance with the law of governing value added tax, 2) at its own determination - if a holder of a family agricultural holding listed in the register of agricultural holdings is in accordance with the regulations governing the registration of farms that chose to have the status of entrepreneur.

The Law of Agriculture and Rural Development (2013) give amendments to Company Law in terms of interpretation whether farmers are entrepreneurs or not. In accordance with this Law, the holder of family farm is individual-farmer and entrepreneur that performs agricultural production, and is registered in the Register of agricultural holdings, as bearer of family farm.

We depart from the regulatory definition of entrepreneurs in agriculture and we consider that entrepreneurs are all farmers who produce exclusively for the market. In terms of our research we consolidate farmers and entrepreneurs engaged in agricultural production. Entrepreneur as a legal form of performing economic activities defined by the Company Law should be distinguished from the term entrepreneur or entrepreneurship in general and particularly in agricultural production. The term entrepreneur is much broader and is not linked to a specific legal form of performing economic activities. In developed countries a distinction between the concept of entrepreneurship and legal form have been made in which this legal form is called individual ownership.

As a small entrepreneur, farmer follows the market, price movements and changes and in accordance with the market creates its business policy. Among other things, this means that farmer should grown crops for which there is a shortage on market, but also a great demand. Also, agricultural entrepreneur the same should apply to livestock production. 
Deregulation in agriculture accompanied by liberalization necessary transforms farmers into small entrepreneurs. In terms of opening our country to the EU market, it is essential that farmers are not just producers but above all entrepreneurs. Entrepreneurial approach to agricultural production in local conditions is essential in order to take advantage offered by the larger market. The basis for the development of an entrepreneurial approach to agricultural producers is awareness of farmers, education, government support and investment, not only in manufacturing but also in the placement and knowledge. The development of an entrepreneurial approach to agriculture is particularly important in Serbia, bearing in mind the economic importance of the agricultural production as well as the potential that can be realized. In this paper, we will show a comparative importance of agriculture in Serbia and region, the European Union and the average of the world.

Agricultural production has enormous social and economic significance in Serbia (see Figure 1). It participates with $10.8 \%$, and if included food industry with $18 \%$ in GDP, employs $23 \%$ of total employment or $17 \%$ of the active population and in export accounted with $23.3 \%$ (Petrović, Njegomir, Počuča, 2013). Due to favorable climatic conditions, a relatively large arable land per resident than the average in Europe, signing the free trade agreement CEFTA, proximity to markets and prospective accession to EU membership, agro-industry has great potential for further development.

Figure 1. The importance of agricultural production in Serbia compared to other countries in the region, the European Union and the average in the world, measured by the share of agricultural production in GDP in the period from 2000 to 2014.

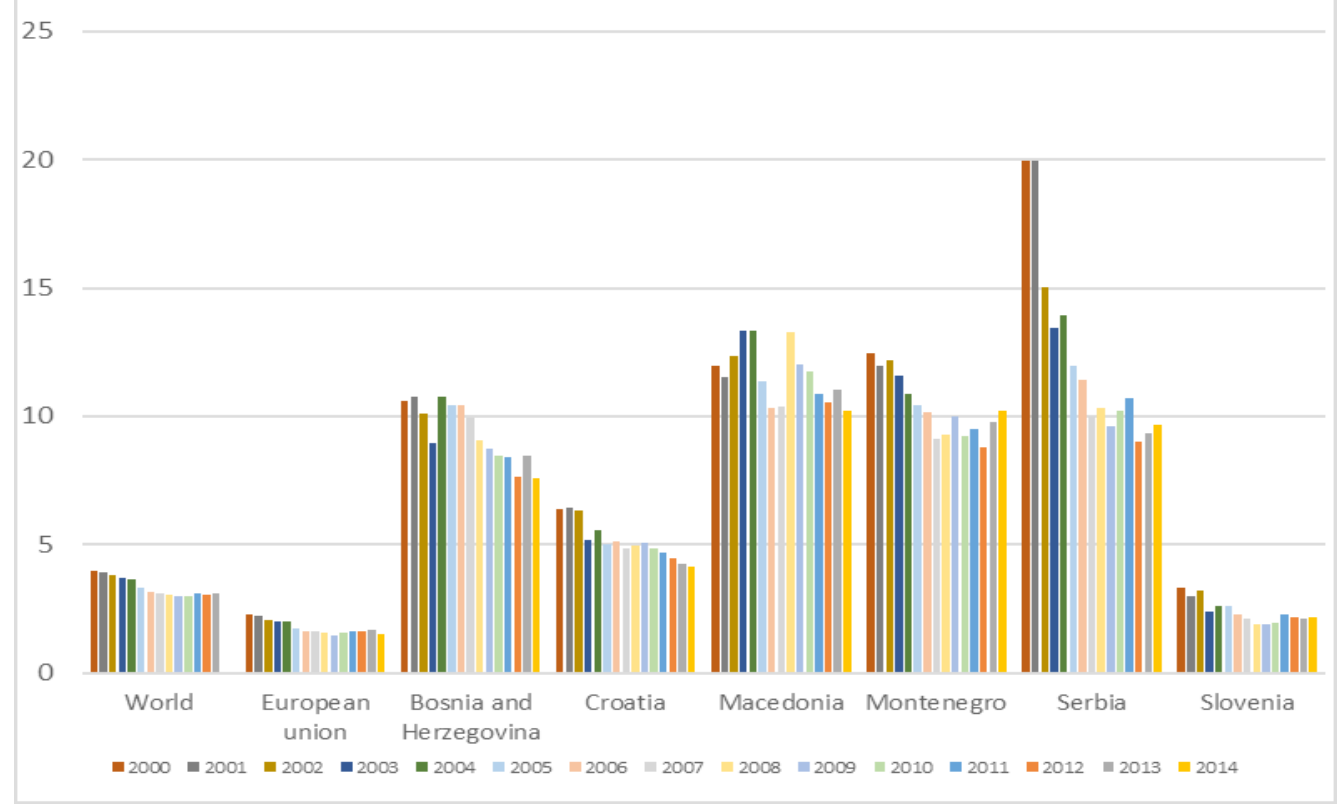

Source: WB (2015). 
The data shown in the chart explicitly point to the fact that agriculture has enormous significance in Serbia in the previous period. At the beginning of observed period the role of agriculture was important but then decreased, but also at the end of period the importance of agricultural production, measured by the contribution of agriculture in gross domestic product is significantly higher than in other countries in the region, except for Macedonia and Montenegro, the average in the European Union or of the average in the world.

\section{Environmental protection as a preventive measure for agricultural entrepreneurship}

Concept development and the climate change problem associated with this concept which has negative effects on all areas, especially in the agriculture, is a complex, global, national and international phenomenon to who it is necessary to devote full attention. The current concept of "unsustainable development" is based on the paradigm of profit economy and the dominance of multinational companies. It basically involves environmental pollution. Environmental pollution can stem from many sources such as: chemicals, industrial wastes, radiation substances, dangerous pesticides, insecticides, nuclear waste, plastic products, and many others. Ecological destruction is a side effect of the current paradigm of development. So far, environment considered as free good (the gift of nature) is mercilessly exploited which left and leaves multiple negative consequences. Endangering the environment contributes to further jeopardizing of agricultural production through the impact of the climate change.

Economically ecological crisis is expressed as: (1) environmental degradation due to increased production based on the exploitation of energy resources and raw materials; (2) contamination of water, food and air; (3) due to shorten lifespan, reduction of working capacity and the basic conditions and parameters of lifr quality and(4) endangering natural environmental conditions (holes in the ozone layer, the greenhouse effect due to excessive $\mathrm{CO} 2$ emissions, energy and social entropy with the possibility of "heat death" of the planet Earth. Those effects have a negative impact on the performance and sustainability of entrepreneurship in agricultural production. Environmental protection is essential not only to the formal protection of the environment but also as a preventive measure to protect agricultural entrepreneurship.

In order to ensure environmental safety, it is necessary to realize the myriad conditions that are the basis for sustainable development of the environment and ecology and life in it. In order to accurately determine what constitutes a problem of environmental security it is necessary to point out the myriad of questions that structure the problem of ecological life with inevitable concepts such as: environment, ecological security and life in that area. In order to ensure environmental security and the life in the ecosystem, it is inevitable conditional rejection and prohibition of all forms of endangering the ecosystem. Preventive and repressive protection of ecosystems provides the conditions and quality of life on Earth and its ecosystem. The prohibition and elimination of the use and the use of dangerous chemical, biological, radiological and other hazardous substances in agriculture, to provide quality living conditions on the planet. The prohibition and elimination of the use and utilization of dangerous chemical, biological, radiological and 
other hazardous substances in agriculture provide quality living conditions on the planet. "Therefore, the basic and first-class condition is not to use dangerous resources in order to achieve adequate protection of ecosystems and life in it" (Marković, Pejanović, 2012).

\section{The role of agricultural insurance in the protection of agricultural entrepreneurship}

Agricultural insurance is a special type of insurance and it is part of property insurance. Insurance companies in the world and in our country, recognizing the specific nature of agriculture insurance, set up special departments to deal with this type of insurance or the acquisition of this type of insurance is left to specialized agencies.

The key role of insurance in agricultural production and society in general is indirect economic protection of life and property from the effects of natural forces and accidents. Insurance improves agricultural production because it makes entrepreneurial activity of agricultural producers more stable and more certain.

Insurance reduces the uncertainty of agricultural producers and the need to create individual saving accounts or funds, given that the need for cash reserves is reduced (Raulston, et al., 2010). By releasing the need for accumulation of surplus funds, which thanks to insurance can be profitably engaged, insurance further provides support for agricultural development (Njegomir, Pejanović, 2011).

Insurance represents indirect economic protection for destructive effects of natural forces and human activities but also represents a form of security pledge (collateral) that allows agricultural producers easier access to capital trough loans at lower costs. The exclusion of state subsidies for the payment of insurance premiums from the Free Trade Agreement from 1994 by World Trade Organization testifies about importance of agriculture insurance. Condition was that insurance provides financial compensation for the climate and natural disasters (Baez, Wong, 2007).

\section{The analysis of agricultural insurance in Serbia}

Taking into account its social and economic importance, insurance protection of agricultural production has special social interest in Serbia. An important place in the measures for the protection and promotion of agriculture takes insurance, in particular insurance:

- Crops, or plant production and

- Domestic and other types of animals.

Insurance is included in the great effort for the promotion and protection of plant production. Compensation covers everything destroyed with occurrence of the insured event fulfilling its important function of the economic protection of agricultural production.

Insurance of domestic animals gives our livestock substantial contribution to maintain the continuity of livestock production. It is equally important for the wider implementation of veterinary and sanitary measures in eliminating the causes that can cause damage and rescuing when the insured event has already occurred. 
The turning point in the development of the insurance market in Serbia was the adoption of the Insurance Act in 2004 and the allocation of supervisory jurisdiction to National Bank of Serbia. Changes in regulation and supervision of the insurance industry introduced order in the insurance market evidenced by the decline in the number of insurance companies from 38 in June 2004 to 17 at the end of 2006. This law, liberalization and market potential contributed to the arrival of foreign investors (Njegomir, Stojić, 2011). Today, most insurance companies in Serbia and in the region of the former Yugoslavia are majority foreign ownership (Njegomir, Stojić, 2010).

In Serbia, agricultural insurance market traditionally offers products of indemnified character and its application is in the form of crop and animal insurance. The dominant type of insurance in the structure of agriculture insurance premiums is insurance of crops and fruits. Characteristics of crop and animal insurance are almost identical for all insurance companies in Serbia. Also, to a large degree is returned confidence in the institution of insurance is restored to the great extent.

In the observed ten-year period of agriculture insurance development from 2004 to 2014, the premium of crop insurance has manifested a continuous upward trend until 2008, then in 2009 we had a significant drop due to the impact of the global economic crisis that began in IV quarter of 2008 (see table 1). In 2010, there was a slight but positive growth. Also, the end of the observed period is characterized by continued growth in premiums. The entire observed period in the field of crop insurance ends with significantly higher premium compared to 2004. Tendencies in the movement of the total insurance premiums of agriculture are fully consistent with the movement of the premium crop insurance, type of insurance whose share is dominant in the structure of agricultural insurance premiums. When it comes to the animals insurance, there was also an upward trend until 2008 and fall in 2009. In this type of agricultural insurance decline in the total volume of insurance premiums continued in 2010 and 2011. In 2012 was achieved a remarkable growth over $62 \%$ compared to the previous year, but already in 2013 there was a decline in the level of premiums and in 2014 there was a slight growth in premiums. 


\begin{tabular}{|c|c|c|c|c|c|c|c|c|c|c|c|c|c|c|c|c|c|c|c|c|c|}
\hline 志 & $\begin{array}{l}8 \\
8 \\
8 \\
\varnothing ్\end{array}$ & 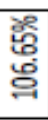 & 号 & 曽 & 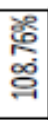 & 造 & 管 & 岩 & 芯 & 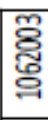 & 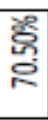 & $\stackrel{\infty}{\widehat{్}}$ & $\begin{array}{l}\text { 艿 } \\
\text { ন }\end{array}$ & 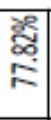 & 亭 & 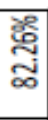 & 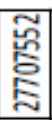 & $\begin{array}{l}80 \\
\text { 总 } \\
\text { + }\end{array}$ & $\begin{array}{l}\text { 옥 } \\
\text { ఠై }\end{array}$ & & 徣 \\
\hline 営 & $\begin{array}{l}\text { 윽 } \\
\text { ஜू. }\end{array}$ & $\begin{array}{l}\text { గ్రి } \\
\text { ஜृ }\end{array}$ & $\begin{array}{l}\infty \\
006 \\
0 \\
0\end{array}$ & 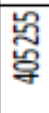 & $\frac{\text { 势 }}{\text { 号 }}$ & 帚 & 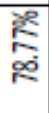 & 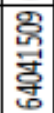 & 용 & ซึ & 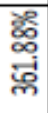 & 잉 & $\begin{array}{l}\stackrel{\Xi}{\Im} \\
\text { g }\end{array}$ & 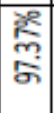 & స్్ㄱ & 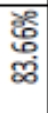 & 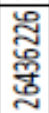 & $\begin{array}{l}30 \\
\text { హ0 } \\
0\end{array}$ & $\frac{2}{8}$ & 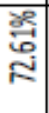 & \\
\hline 롱 & 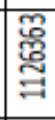 & 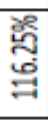 & 营 & $\begin{array}{l}\text { कू } \\
\text { 多 }\end{array}$ & 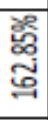 & ్ㅠㄱ & 縹 & 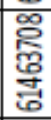 & 离 & $\begin{array}{l}\frac{m}{\Xi} \\
\stackrel{్}{\sigma}\end{array}$ & $\begin{array}{l}\text { హె } \\
\text { రై } \\
\end{array}$ & 学 & 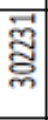 & 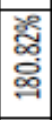 & \%్ & 羿 & 宊 & 洛 & 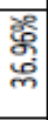 & $\begin{array}{l}\text { 孚 } \\
\text { o } \\
0\end{array}$ & \\
\hline & $\begin{array}{l}\text { Љू } \\
\text { \& }\end{array}$ & 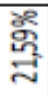 & 善 & $\begin{array}{l}8 \\
8 \\
8\end{array}$ & $\frac{3}{9}$ & 离 & $\begin{array}{l}\text { 总 } \\
\text { कू }\end{array}$ & $\begin{array}{l}\text { \% } \\
\text { \%্ল } \\
\end{array}$ & 疍 & 륭 & 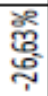 & శ్రిల్ల & $\underset{⿱ 乛}{\frac{9}{2}}$ & 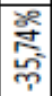 & 㐨 & $\underset{\infty}{\stackrel{2}{2}}$ & 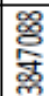 & 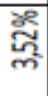 & 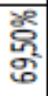 & 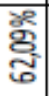 & \\
\hline
\end{tabular}

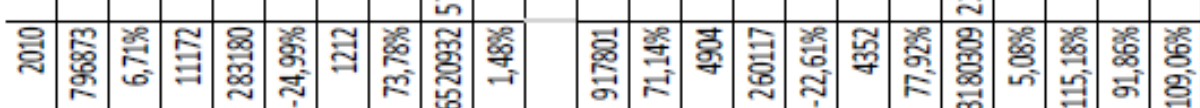

ஓి

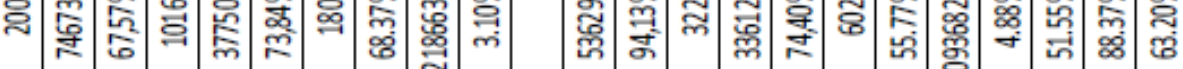

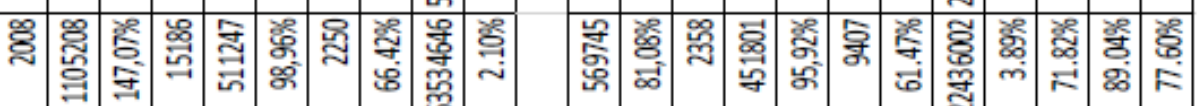

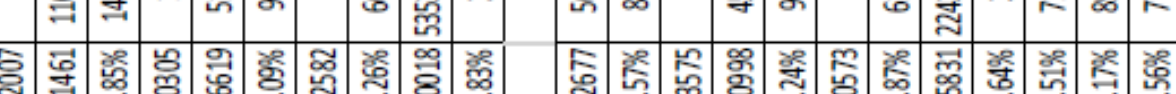

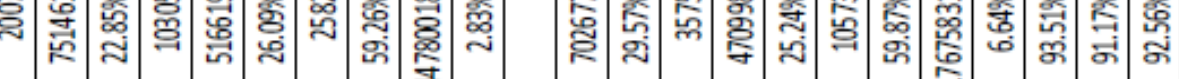

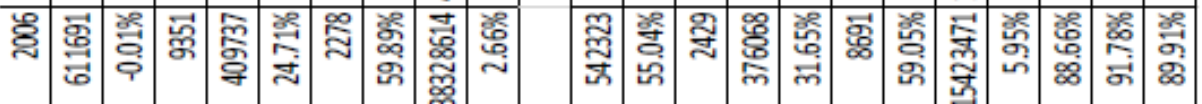

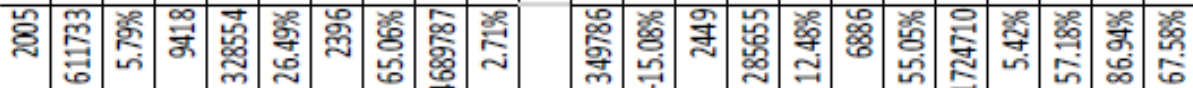

さ 
It is evident that agricultural insurance, a synthesis of crop and animal insurance, represents a negligible portion of the total premium of insurance companies in Serbia. The share of agriculture insurance in total insurance premiums of insurance companies in Serbia at the beginning of the observed period amounted $3.70 \%$ at the end $2.95 \%$, while the lowest level of participation reached in 2010, when this share was only $1.48 \%$. These figures imply that there is low demand for insurance, especially if these data are analyzed in combination with data on the number of insurance. However, this data should be considered in the context of the damage based on the share of claims on the agricultural insurance in total insurance losses of insurance companies. These figures are significantly different from the information on the premiums. Share of claims on the agricultural insurance in total claims of insurance companies in Serbia at the beginning of the observed period was 7.57\% and $4.66 \%$ at the end, except that during the entire period of only five years was below $5 \%$. It is evident that during the observed period, share of agricultural insurance in total insurance is disproportionately high. All this leads to conclusion about insufficient demand for insurance as well as the inevitable consequence of the lack of interest of insurance companies to develop insurance for this segment of its activities due to reduced profitability.

Finally, the loss ratio or technical result as one of the most significant indicators of profitability in the insurance business reflects the fact that, observed on average for all insurance companies in Serbia, agricultural insurance is unprofitable. The loss ratio represents the ratio of relevant damage and relevant retention premium. The relevant retention premium is retention premium realized in the current year increased by the amount of the premium in retention calculated at the end of last year and decreased by the amount of unearned premiums in retention calculated at the end of current year. Relevant claims in retention are total of resolved claims in retention during the current year increased by the amount of outstanding claims in retention at the end of the current year and the reduction of the amount of outstanding clams in retention at the end of previous year and the amount of collected recourse during the current year. Essentially, the loss ratio presents information to what extent the collected premiums were sufficient to cover any damage during given (observed) period. It is desirable that this ratio as low as possible, and if it is over $100 \%$ this actually means that the insurance company should pay for damages more than it collected insurance premiums.

The loss ratio in crop insurance theoretically speaking, throughout the period, with the exception of 2010 and 2013, indicated that the insurance companies in Serbia on the basis of this type of insurance achieved a positive result, and had access to certain premium surpluses compared to the damage. However, except for having expenses for claims, insurance companies have operating costs, which are especially high in the domain of agriculture insurance, and the fact that the average value of claim ratio in Europe is in the range from $60 \%$ to $70 \%$ of insurance premiums, it is clear that a bad claim ratio was made in 4 years and in other years that ratio was at the maximum level of the european average. The best result was achieved in 2012. In the animal insurance situation is significantly worse although throughout the observed period, loss ratio pointed to positive result in the operations of insurance companies in Serbia. Sublimated, the loss ratio in agriculture insurance from insurance companies in Serbia was also inadequate, especially in 2010. 


\section{Conclusion}

The development of an entrepreneurial culture in agricultural production is essential because it is often neglected, not only legally, but also in the practice of agricultural producers. Involvement of agricultural producers not only in primary agricultural production but also in processing of agricultural products as a whole or in a particular level is extremely important for the development of agriculture in Serbia as well as for development of rural areas. Development of agricultural production based on the improved profitability can enable the return of young people to agriculture.

The need for encouraging entrepreneurship is not only important in developing countries such as Serbia but also in the countries of the European Union. Entrepreneurship needs to be nurtured through the different stakeholders, above all, association of farmers, science and government agencies.

Every aspect of entrepreneurial activity is exposed to the effects of risk. In the definition of entrepreneurship provided by the European Commission is cited the risk exposure and the need for a willingness to accept risk. Acceptance of risk is just as important as the entrepreneurial spirit, creativity and innovation and by that it is meant the acceptance of the risk that entrepreneurs-agricultural producers are able to influence.

The risks for agricultural production imposed by climate change include the risks that require intervention. Preventive intervention is possible through the protection of the environment as well as through insurance. Agricultural insurance is the most important mechanism for the protection of entrepreneurial activity in agricultural production. Based on the existence of insurance in term of flood realization that is recorded in Serbia in 2014 and 2016, drought as it was in 2012, as well as precipitation with the hails that destroy crops such raspberry crops destroyed in 2016, entrepreneurial activities of agricultural producers are safer and more certain. Also, thanks to the existence of insurance increases the willingness of agricultural entrepreneurs to undertake business ventures.

\section{Literature}

1. Acs, Z.J. (2008): Foundations of High Impact Entrepreneurship. Foundations and Trends in Entrepreneurship, Vol. 4, No. 6, pp. 535-620.

2. Baez, M.S. and Wong, S. (2007): Insurance in emerging markets: sound development; greenfield for agricultural insurance. Sigma No 1/2007, Swiss Re, Zurich.

3. Birovljev, J. and Tomić, R. (2009): Menadžment u agrobiznisu. Ekonomski fakultet, Subotica.

4. Cantillon, R. (1931): Essai sur la nature du commerce en général. Edited and translated by Higgs, H. MacMillan, London.

5. Company Law (2015): Zakon o privrednim društvima, „Official Gazette of the RS”, no. 36/2011, 99/2011, 83/2014 - other Law.

6. Green Paper (2003): Entrepreneurship in Europe. Commission of the European 
Communities, COM(2003) 27 final, Brussels.

7. Ireland, R.D., Webb, J.W.(2007): A Cross-Disciplinary Exploration of Entrepreneurship Research. Journal of Management, Vol. 33, pp. 891-927.

8. Law of Agriculture and Rural Development (2013): Zakon o poljoprivredi i ruralnom razvoju, „Official Gazette of the RS “, no. 41/2009 and 10/2013 - other law.

9. Law on Personal Income Tax (2015): Zakon o porezu na dohodak građana, „Official Gazette of the RS", no. 24/01 , 80/02 - other law, 80/02, 135/04, 62/06, 65/06 correction, 31/09, 44/09, 18/10, 50/11, 91/11 - US, 93/12, 114/12 - US, 47/13, 48/13 - correction, 108/13, 57/14, 68/14 - other law, 112/15.

10. Marković, S., Pejanović, Lj. (2012): Zaštita životne sredine. Fakultet za pravne i poslovne studije dr Lazar Vrkatić, Novi Sad.

11. McElwee, G. (2005): Developing entrepreneurial skills of farmers: Literature review of entrepreneurship in agriculture. The report pruduced with financial support form the Commmission of the European Community, Brussels.

12. MFRC (2016): Ministarstvo finansija Republike Sribije, http://www.mfin.gov.rs/ UserFiles/File/misljenja/2013/Objasnjenje\%20vodjenje\%20poslovnih\%20knjiga(1). pdf (accessed 08.06.2016.)

13. Njegomir, V., Pejanović, R. (2016): Climate change risks, agricultural production, and the role of insurance. Ekonomika poljoprivrede, accepted for publication.

14. Njegomir, V., Pejanović, R. (2011): Importance and current issues in agricultural insurance in Serbia. Contemporary Agriculture, Vol. 60, No. 1-2, pp. 38-45

15. Njegomir, V., Stojić, D. (2010): Determinants of insurance market attractiveness for foreing investments: the case of ex-Yugoslavia. Economic Research, Vol. 23, No. 3, pp. 96-110.

16. Njegomir, V., Stojić, D. (2011): Liberalisation and market concentration impact on performance of the non-life insurance industry: the evidence from Eastern Europe. The Geneva Papers on Risk and Insurance - Issues and Practice, Vol. 36, No. 1, pp. 94-106.

17. Petrović, Z., Njegomir, V., Počuča, S. (2013): Characteristics of agricultural insurance: the case of countries of former Yugoslavia region. Ekonomika poljoprivrede, Vol. 60, No. 4, 2013, pp. 729-745.

18. Raulston, J.M., Richardson, J.W., Outlaw, J.L., Knapek, G.M. (2010): Does Crop Insurance Reduce the Need for Cash Reserves in Savings Accounts? Paper presented at the SAEA Annual Meeting, Orlando, FL.

19. Schumpeter, J A. (1934): The Theory of Economic Development. Harvard University Press, Cambridge, MA.

20. Stefanović, R., Obradović, S., Broćić, Z. (2012): Perspektive i razvojni izazovi preduzetništva u poljoprivredno-prehrambenom sektoru Republike Srbije. Učenje za poduzetništvo, Vol. 2, No. 2, pp. 371-380.

21. Tyszka, T., Cieslie, J. Domurat, A., Macko, A. (2011): Motivation, Self-Efficacy, and 
Risk Attitudes Among Entrepreneurs During Transition to a Market Economy. Journal of Socio-Economics, Vol. 40, No. 2, pp. 124-131.

22. WB (2015): World bank, http://data.worldbank.org/indicator/NV.AGR.TOTL.ZS/ countries (accessed 15.06.2015.)

\title{
PREDUZETNIŠTVO U POLJOPRIVREDI, EKOLOŠKA ZAŠTITA I OSIGURANJE
}

\section{Vladimir Njegomir ${ }^{4}$, Ljubo Pejanović, Zoran Kekovic ${ }^{6}$}

\begin{abstract}
Rezime
Preduzetništvo u poljoprivredi je u osnovi kreativnosti, inovativnosti, profitabilnosti $i$ upravljanja rizicima poljoprivrednih proizvođača. Iako se preduzetništvo u poljoprivredi često zanemaruje u Srbiji, u radu naglašavamo njegov značaj s obzirom na činjenicu da je doprinos poljoprivrede još uvek najveći za bruto domaći proizvod. Tekuća 2016. godina proglašena je za godinom preduzetništva u Srbiji, što je dodatno naglasilo značaj izučavanja ove problematike. Za cilj rada smo odredili potrebu izučavanja preduzetništva u poljoprivredi u kontekstu ugroženosti rizicima iz okruženja. U tom smislu, u radu prvo ukazujemo na preduzetništvo u poljoprivredi i značaj poljoprivredne proizvodnje u Srbiji a potom ukazujemo na ekološku zaštitu, kao oblika preventivnog delovanja na redukciju rizika i osiguranje, kao oblika finansiranja posledica ostvarenja šteta i karakteristike osiguranja poljoprivrede u Srbiji. Osnovni zaključak je da ekološka zaštita i osiguranje poljoprivrede predstavljaju komplementarne mehanizme zaštite od rizika koji pružaju značajnu podršku preduzetništvu u poljoprivredi i razvoju poljoprivredne proizvodnje.
\end{abstract}

Ključne reči: poljoprivreda, preduzetništvo, klimatske promene, osiguranje, Srbija.

4 Vanredni profesor, dr Vladimir Njegomir, Fakultet za pravne i poslovne studije dr Lazar Vrkatić, Bulevar oslobođenja br. 76, 21000 Novi Sad, Srbija, Telefon: +381 6413930 05, E-mail: vnjegomir@eunet.rs

5 Vanredni profesor, dr Ljubo Pejanović, Fakultet za pravne i poslovne studije dr Lazar Vrkatić, Bulevar oslobođenja br. 76, 21000 Novi Sad, Srbija, E-mail: pejanovicljubo@gmail.com

6 Redovni profesor, dr Zoran Keković, Univerzitet u Beogradu, Fakultet Bezbednosti, Ulica Gospodara Vučića br. 50, 11040 Beograd, Srbija, Telefon: +381 6912302 65, E-mail: zorankekovic@yahoo.com

EP 2017 (64) 3 (1035-1047) 